\title{
Holocene palynological records and their responses to the controversies of climate system in the Shiyang River drainage basin
}

\author{
LI Yu*, WANG NaiAng, LI ZhuoLun \& ZHANG HuaAn \\ College of Earth and Environmental Sciences, Center for Hydrologic Cycle and Water Resources in Arid Region, Lanzhou University, Lanzhou \\ 730000, China
}

Received August 10, 2010; accepted November 9, 2010

\begin{abstract}
The Shiyang River drainage basin is located in the northwest margin of the Asian monsoon region. Previous studies reached different conclusions about Holocene climatic changes in the basin. Some studies suggested the Holocene climatic changes were mainly controlled by the Asian monsoon and that the climate was relatively humid during the early Holocene (11.6-7.1 cal ka BP). Other studies found the mid-Holocene Climatic Optimum (7.0-5.0 cal ka BP), and this climate condition was similar to the Holocene westerly wind pattern in arid Central Asia. The modern climate is affected by the Asian monsoon and westerly wind in the drainage basin, and the Holocene climatic records showed two different Holocene climatic patterns-a westerly wind pattern and monsoonal pattern. However, it remains unclear what caused the two different Holocene climatic patterns to co-exist in the region. The palynological records are the main evidence for the Holocene climatic changes in the basin. This paper focuses on palynological records for different parts of the drainage basin. Among them, QTH02, QTL-03 and Sanjiaocheng records are located in the terminal lake, and the Hongshuihe record is located in the middle reaches of the basin. In the terminal lake, the palynological records of QTH02 and QTL-03 are similar, but the Sanjiaocheng record differs. The difference is mainly affected by the variable pollen assemblages in the different locations of the lake basin. From comparison and synthesis of the four palynological records, we concluded that the millennial-scale Holocene climatic changes were affected by the combined effects of the Asian monsoon and westerly wind in the drainage basin, which show the complicated Holocene climatic pattern in the northwest margin of the Asian monsoon.
\end{abstract}

Holocene, Asian monsoon, westerly wind pattern, marginal area of the Asian monsoon, palynological records

Citation: $\quad$ Li Y, Wang N A, Li Z L, et al. Holocene palynological records and their responses to the controversies of climate system in the Shiyang River drainage basin. Chinese Sci Bull, 2011, 56: 535-546, doi: 10.1007/s11434-010-4277-y

In 2009, PAGES (Past Global Changes) released their latest science plan and implementation strategy. One of the four themes was regional climate dynamics, for which the Holocene is one of three important periods; this suggests that greater attention will be given to the study of the Holocene [1]. There are many uncertainties relating to Holocene climate change in China, and the climate change processes in China may differ from those in other regions [2]. An et al. [3] initially suggested that Holocene climate changes were asynchronous in the Asian monsoon domain. An et al. [4] found millennial-scale arid events in arid and semiarid regions

*Corresponding author (email: liyu@1zu.edu.cn) during the mid-Holocene, but these drought events occurred at different times in different regions. Records for the western Loess Plateau indicate a humid climate during the mid-Holocene [5]. The above evidence indicates that Holocene climate change was complicated in arid and semiarid China. The Asian monsoon system can be divided into two subsystems: the East Asian monsoon and Indian monsoon [6,7]. In a comparative study of Holocene peat taken from the East Asian monsoon region and Indian monsoon region, Hong et al. [8] concluded there had been anti-phase climate change in the two subsystems. Using stalagmite records, Yang et al. [9] challenged this viewpoint. Absolutely dated stalagmite records studied in recent years indicate that 
Holocene climate change was synchronous in the Asian monsoon domain, and that the Asian monsoon precipitation peaked in the early Holocene before declining [10-12]. However, the Holocene stalagmite records are limited by their distribution, and the synchronous evolution of the Asian monsoon requires further confirmation. The climate was affected by the combined effects of the Asian monsoon and westerly wind in northwest China [13]. Li [14] suggested the climate in northwest China could be divided into a monsoon pattern and westerly wind pattern in terms of the millennium-scale climate change; in the late Pleistocene, the climate of the Xinjiang region was mainly controlled by a westerly wind pattern and that of monsoonal Gansu, Qinghai and other regions was mainly controlled by a monsoonal pattern. Herzschuh [15] synthesized 75 records for the Asian continent and found that the Holocene climate patterns differed between Central Asia and some parts of the Asian monsoon domain. Chen et al. [16] analyzed the absolutely dated Holocene records for the Asian monsoon domain and arid Central Asia and found that Holocene millennium-scale climate patterns differ for the two regions. The difference is mainly due to different evolution histories of the Asian monsoon and westerly wind. Chen et al. [16] then defined the monsoonal and westerly wind patterns in terms of Holocene millennium-scale climate change. The monsoonal pattern is a kind of Holocene climate change; in this pattern, the early Holocene was relatively humid and the climate became drier from the mid-Holocene onward. The westerly wind pattern refers to a climate change from a dry early Holocene to a humid mid-to-late Holocene. (Note that in this paper, the monsoonal and westerly wind patterns are based on millennium-scale climate change and cannot be used to discuss inter-annual and decadal-scale interaction between the Asian monsoon and westerly wind.) Studying Holocene climate change in the marginal area of the Asian monsoon further allows us to explore the mechanism of interaction between the Asian monsoon and westerly wind. Previous studies have found large Holocene climatic differences in the marginal areas of the Asian monsoon [17-20]. Understanding the differences is beneficial to studying the mechanism of the millennium-scale climate change of the Asian monsoon and westerly wind.

In arid and semiarid regions of China, Holocene palynological records are mainly used to reconstruct vegetation and ecology [21-24], while the paleo-ecological condition is mainly controlled by climatic conditions; therefore, the palynological records can be used to reconstruct climate changes. The Shiyang River basin is located in the northwest margin of the Asian monsoon (Figure 1); the basin is near the region controlled by westerly winds. According to previous studies [14-16], Holocene millennial-scale climate change differs between the Asian monsoon region and arid Central Asia. From comparison of the pollen-reconstructed climate of the Shiyang River basin and Holocene records for arid Central Asia and the Asian monsoon region, we can determine the effects of the monsoonal pattern and westerly wind pattern in the basin. For Zhuye Lake, the terminal lake of the basin, Li et al. [21,22] reported the Holocene optimal period was 7.4-4.7 cal ka BP in a palynological study. In addition, at the terminal lake, Zhao et al. [23] suggested the Holocene Climatic Optimum was 7.2-5.2 cal ka BP. These two studies show the Holocene climate is similar to the westerly wind pattern in arid Central Asia. However, for the western part of Zhuye Lake, Chen et al. [24,25] used palynological

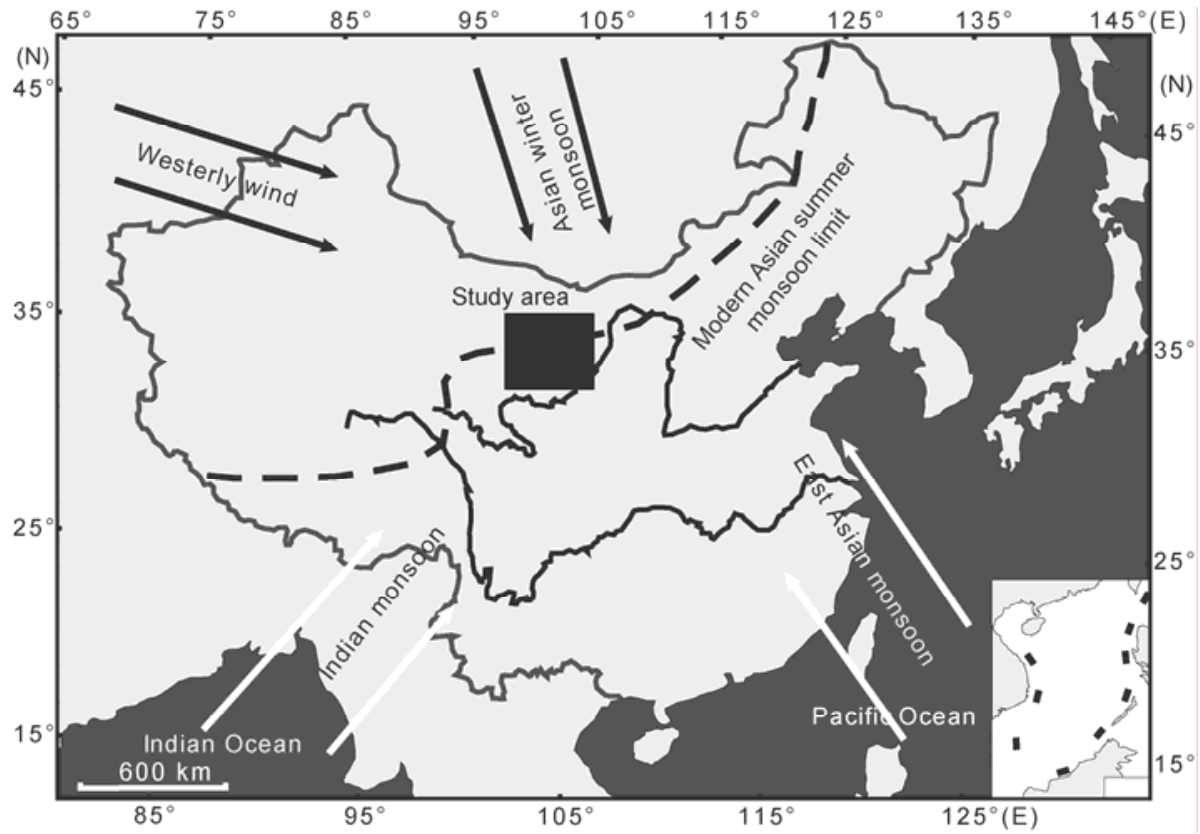

Figure 1 Map showing the study area. The dotted line shows the modern limit of the Asian summer monsoon, and the arrows indicate the climate systems affecting China, including the East Asian monsoon, Indian monsoon, Asian winter monsoon, and westerly winds [13,26]. 
records to determine that the basin was mainly controlled by the Asian monsoon, and that the early Holocene of 11.0-7.0 cal ka BP was the Holocene Climatic Optimum, during which there was relatively high precipitation. These studies suggest different Holocene climate patterns for the same lake. To determine the source of the discrepancies, we compared four pollen records for the basin to explore the pattern of Holocene climate change.

\section{Study area}

The Shiyang River drainage basin is located within the eastern Qilian Mountains region, roughly at geographical coordinates of $100^{\circ} 57^{\prime}-104^{\circ} 57^{\prime} \mathrm{E}, 37^{\circ} 02^{\prime}-39^{\circ} 17^{\prime} \mathrm{N}$. The basin length is about $300 \mathrm{~km}$ and the total area is $4.16 \times 10^{4} \mathrm{~km}^{2}$ (Figure 2). Based on the geographical divisions in China, the Shiyang River drainage basin is in the transition zone of monsoonal and arid regions, and the modern climate of the region is affected by the Asian monsoon and westerly wind [26]. According to modern climate research, the westerly wind comprises a prevailing westerly wind and a westerly jet, both of which make a large contribution to water vapor transportation in the basin [27,28]. In East Asia, the high-altitude westerly jet strongly affects the summer rain belt [29], the spatial distribution of the rainy season [30] and the winter monsoon [31]. Prevailing westerlies and the westerly jet stream affect the climate system via different mechanisms. This paper focuses on millennial-scale climate change, instead of inter-annual and decadal-scale changes; therefore, it is difficult to distinguish the prevailing westerly wind and westerly jet, both of which are recognized as westerly winds in this paper.

The Shiyang River basin can be divided into three climatic zones from south to north. (1) The alpine semiarid area of the southern Qilian Mountains has an altitude of 2000-5000 m, annual rainfall of 300-600 mm, and annual evaporation of 700-1200 $\mathrm{mm}$. The vegetation zones can be divided into the alpine cushion zone (representative plants: Androsace tapete and Ceratoides compacta), alpine meadow zone (representative plant: Kobresia), alpine shrub zone (representative plants: Rhododendron and Potentilla fruti$\cos a$ ), forest zone (representative plants: Picea, Sabina, Populus and Betula), and piedmont meadow steppe zone (representative plants: Stipa breviflora and Achnatherum splendens). (2) The cool and arid central plains have an altitude of 1500-2000 m, annual rainfall of 150-300 mm, and annual evaporation of 1300-2000 $\mathrm{mm}$. The vegetation zone is a desert steppe zone. Poaceae is the dominant vegetation and is accompanied by xerophytic shrubs. (3) The northern warm and dry area has an altitude of 1300-1500 m, annual rainfall less than $150 \mathrm{~mm}$, and annual evaporation of 2000-2600 mm. Desert vegetation, such as Haloxylon ammodendron, Nitraria and Ephedra przewalskii, is widely distributed in this area [32,33]. Zhuye Lake is the terminal lake of the Shiyang River basin. The lake level was relatively high during the historical period [34,35], but the lake is now completely dried up. Pachur et al. [36], Zhang et al. [37,38] and Long et al. [39] have studied the history of the lake evolution since the late Pleistocene, by dating the

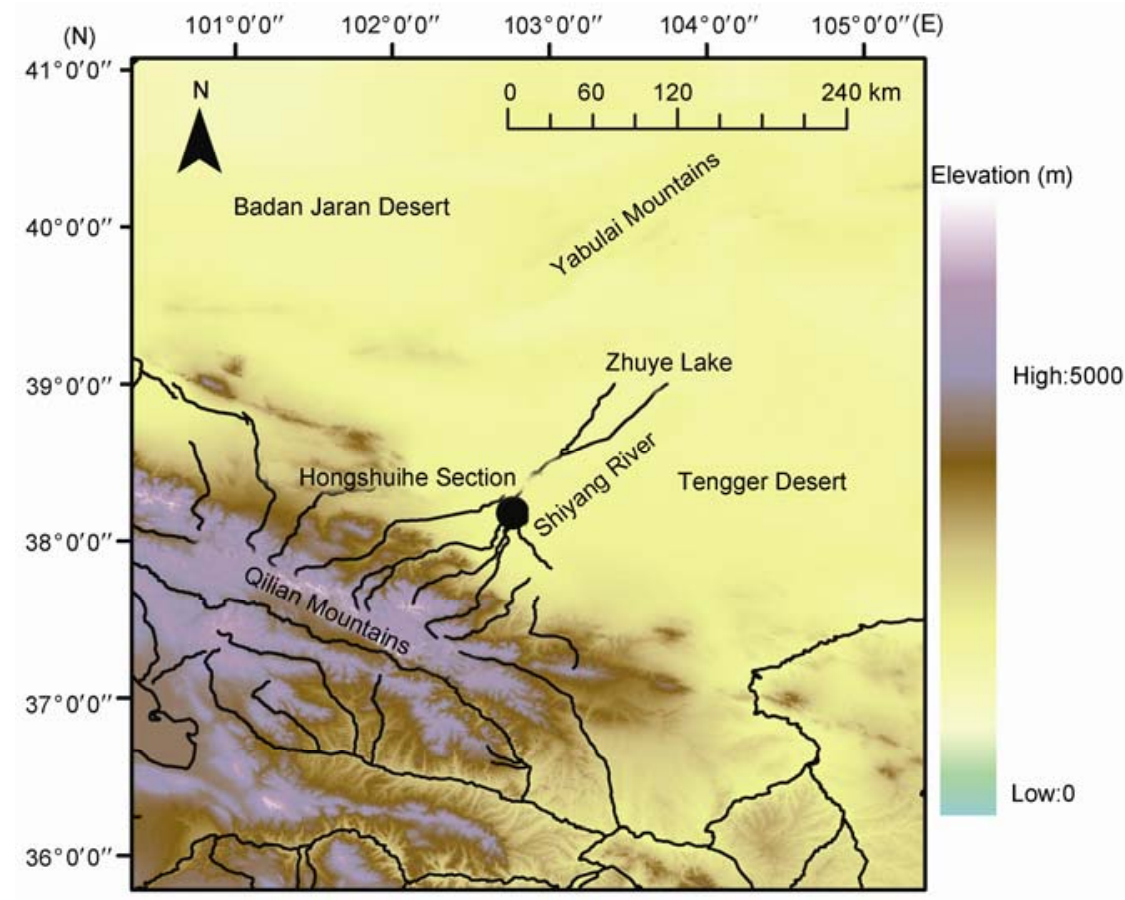

Figure 2 Map showing the topography around Zhuye Lake and the Shiyang River drainage basin. The black circle indicates the Hongshui River section in the middle reaches of the basin. 
northeast paleoshorelines of the lake. During the Holocene epoch, the studies showed that the lake level was high in the early and middle Holocene and relatively low during the late Holocene. The Zhuye basin comprises sub-basins, such as the lakes of Baijian, Dongxiao, Xixiao Lake, Yema and Qingtu (Figure 3). According to a field investigation and analysis of topographic maps, the sub-basins are connected by channels; therefore, the lake level is consistent among the sub- basins.

\section{Materials and dates}

QTH01 and QTH02 sections were excavated in the central part of Zhuye Lake. The two sections are separated by $8 \mathrm{~m}$ at an elevation of $1309 \mathrm{~m}$ above sea level. The geographic coordinates are $39^{\circ} 03^{\prime} 00^{\prime \prime} \mathrm{N}, 103^{\circ} 40^{\prime} 08^{\prime \prime} \mathrm{E}$ (Figure 3). From the lithology and grain size, the dates for the two sections can be mutually extrapolated [21,22]. Pollen samples were collected from the QTH02 section [23]. QTL-03 has geographic coordinates of $39^{\circ} 04^{\prime} 15^{\prime \prime} \mathrm{N}, 103^{\circ} 36^{\prime} 43^{\prime \prime} \mathrm{E}$ and an altitude of $1302 \mathrm{~m}$ (Figure 3). The Sanjiaocheng section [24,25] has geographic coordinates of $39^{\circ} 00^{\prime} 38^{\prime \prime} \mathrm{N}, 103^{\circ} 20^{\prime} 25^{\prime \prime} \mathrm{E}$ at an altitude of $1320 \mathrm{~m}$ (Figure 3). The Hongshuihe section $[40,41]$ is located on a terrace of the Hongshui River, which is a tributary of the Shiyang River, in the middle reaches of the Shiyang River, at the altitude $1460 \mathrm{~m}$ (Figure 2). The Hongshuihe section in fact comprises two sections $1 \mathrm{~km}$ apart at geographic coordinates of $38^{\circ} 10^{\prime} 46^{\prime \prime} \mathrm{N}, 102^{\circ} 45^{\prime} 53^{\prime \prime} \mathrm{E}$. Joining the two sections, we obtain a continuous Holocene record for the middle reaches of the Shiyang River. The sedimentary facies of the Hongshuihe section are mostly controlled by the environmental conditions in the middle and upper reaches of the basin. Lacustrine sediments and peat formed during the humid period and sediments were dominated by sand and aeolian sediments during the arid period [40,41]. Figure 4 shows the lithology and dates for the QTH01, QTH02, QTL-03, Sanjiaocheng and Hongshuihe sections. In the Shiyang River basin, the Holocene sediments are mainly dated employing the ${ }^{14} \mathrm{C}$ dating method; however, ${ }^{14} \mathrm{C}$ dating of lake sediments is easily affected by hard water. Wang et al. [42] have reported the 2500-year hardwater effects for the middle part of the Hexi Corridor. To understand the hardwater effects of Zhuye Lake sediments, Li et al. [21] surveyed two sets of dating samples taken at depths of 315 and $425 \mathrm{~cm}$. At the depth of $315 \mathrm{~cm}$, the bulk organic matter indicated an age of $4130 \pm$ $110 \mathrm{a}$, and the AMS ${ }^{14} \mathrm{C}$ age of shells indicated an age of $4160 \pm 40$ a. At the depth of $425 \mathrm{~cm}$, the bulk carbonate indicated an age of $5960 \pm 65$ a, and the AMS ${ }^{14} \mathrm{C}$ age of shells indicated an age of $5920 \pm 40$ a. There is little difference between the dates derived from the organic matter and shells; therefore, we consider that the hardwater effects are weak. Meanwhile, Chen et al. [43] studied the hardwater effects for the Sanjiaocheng section. The result only presented hardwater effects for a period of 550 years, but again indicated weak hardwater effects. Zhang et al. [40] reported ${ }^{14} \mathrm{C}$ dating for terrestrial plant debris (tree branches and root debris) in the Hongshuihe section, and compared these dates with the dates obtained for upper and deeper parts. The results again indicate that the hardwater effects were relatively small in the Hongshuihe section. The above studies show that the QTH01, QTH02, QTL-03, Sanjiaocheng and Hongshuihe sections are less affected by hard water in the Shiyang River basin; therefore, dating errors have less effect on the discussion of the millennium-scale Holocene climate pattern.

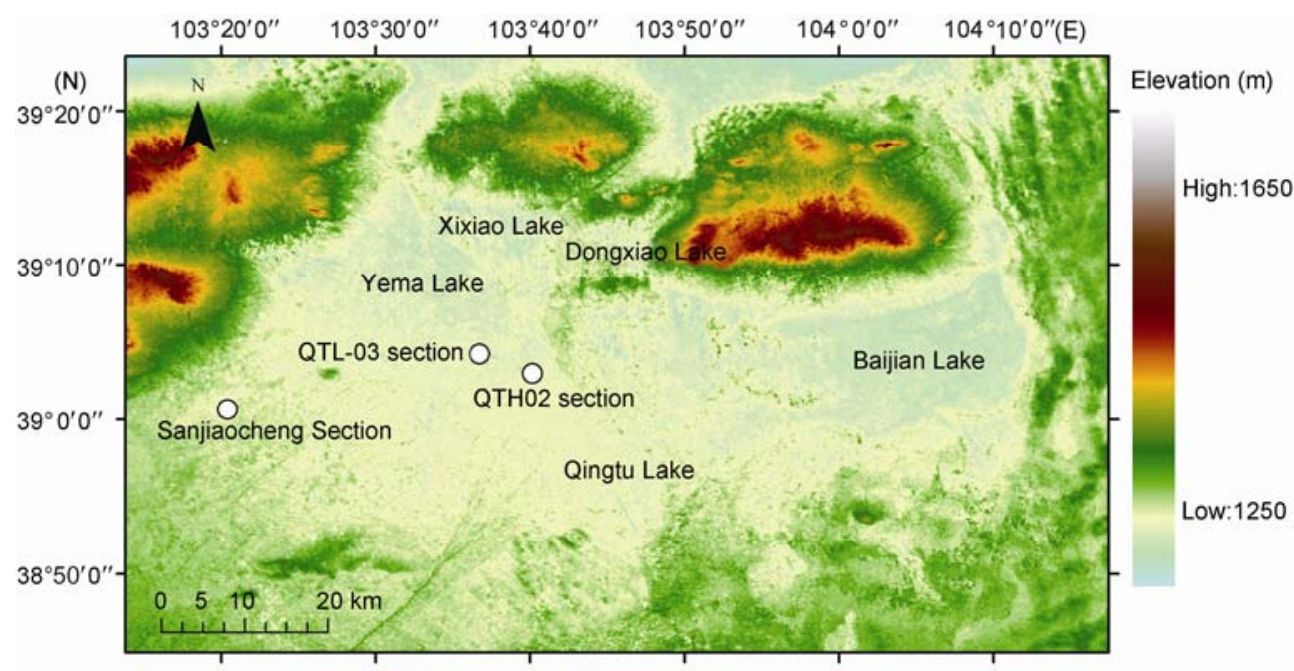

Figure 3 Map showing the latitude, longitude and elevation of the Zhuye Lake basin. Baijian Lake, Yema Lake, Qingtu Lake, Xixiao Lake and Dongxiao Lake are the sub-basins of Zhuye Lake. The white circles indicate the QTH02, QTL-03 and Sanjiaocheng sections. The elevation data are based on the ASTER-GDEM dataset with $30 \mathrm{~m}$ resolution, downloaded from https://wist.echo.nasa.gov/wist-bin/api/ims.cgi?mode=MAINSRCH\&JS=1. 


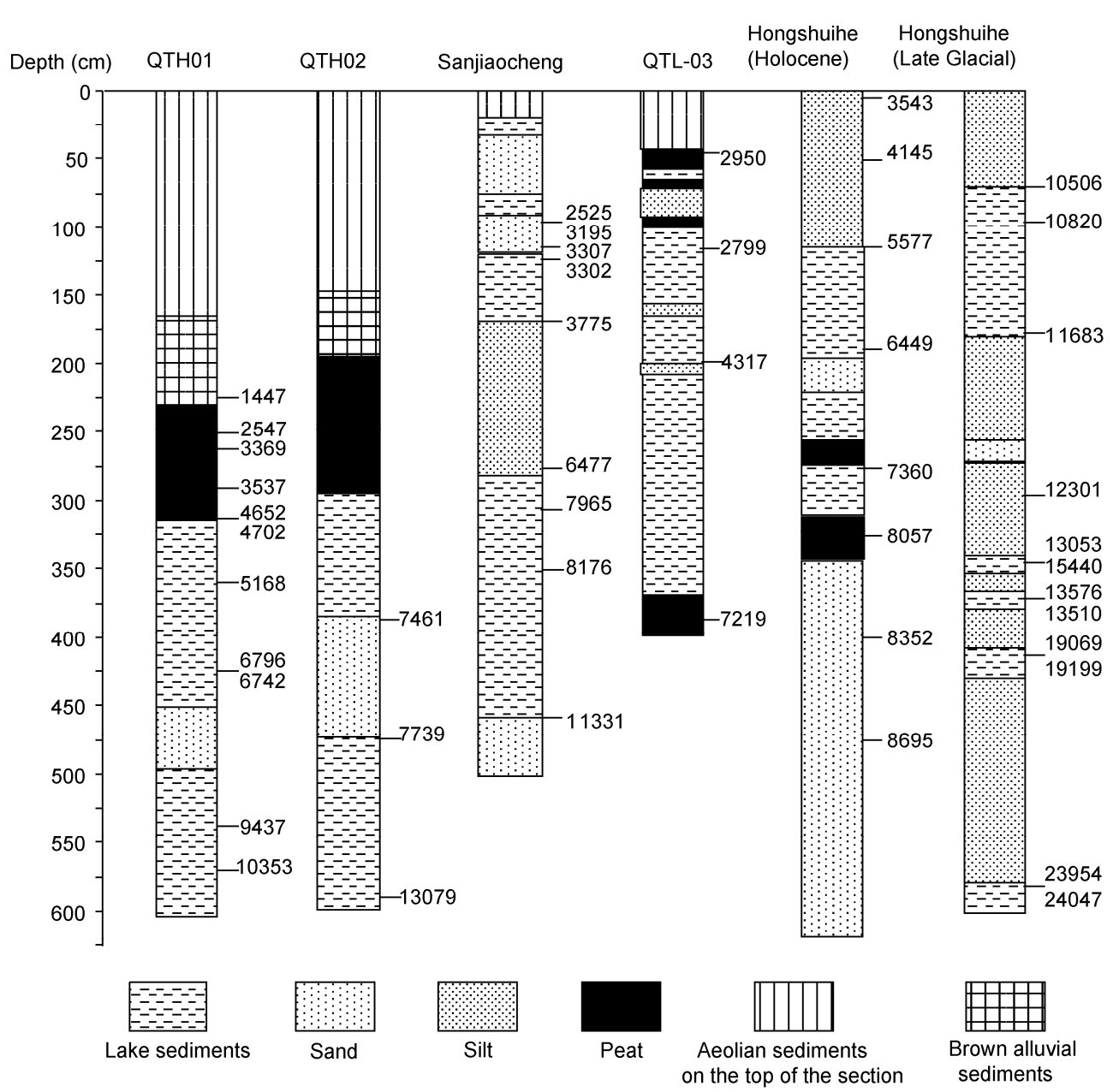

Figure 4 Lithology and dates obtained from the QTH01 [21,22], QTH02 [21,22], QTL-03 [23], Sanjiaocheng [24], and Hongshuihe [40,41] sections. There are two Hongshuihe sections: one is for the Holocene and the other is for the Late Glacial. Using Calib5.01 software, all ${ }^{14} \mathrm{C}$ dates are calibrated to the calendar year.

\section{Palynological records of the Shiyang River drainage basin}

\subsection{Holocene palynological records of the QTH02 section}

The QTH02 section is located in the middle of Zhuye Lake (Figure 3); dating and pollen analysis were completed by the authors of this paper. Through sampling of the section at $10 \mathrm{~cm}$ intervals, 74 pollen samples were analyzed. The calculations for all the samples were for more than 100 grains, and the calculations for most of the samples were for more than 500 grains. For the Holocene epoch, the section can be divided in to A, B and C phases (Figure 5). During phase A (11.0-7.4 cal ka BP), herb pollen accounts for 43\%-97\% ofthe grains ( $72 \%$ on average), with Artemisia accounting for the largest proportion. The percentages of tree pollen reach their highest levels during the Holocene, averaging 14\%, with the needle trees Pinus and Picea being dominant. The total pollen concentration is between 80 and 209 grains/ g. During phase B (7.4-4.7 cal ka BP), the total pollen con- centration increases significantly, averaging 38634 grains/g. The average contributions of Artemisia and Chenopodiaceae are $76 \%$ and $13 \%$. The contribution of tree pollen is relatively low; however, the tree pollen concentration reaches a maximum of 1232 grains/g during the Holocene. The Picea pollen concentration also reaches the highest Holocene level of 382 grains/g. During phase C (4.7-0 cal ka BP), the pollen assemblages are dominated by herbs, and the average contribution by herbs is $90 \%$. The total pollen concentration decreases, averaging 2242 grains/g. The tree pollen percentages and concentrations are low, with the tree pollen concentration averaging 58 grains/g. The Artemisia pollen percentage declines, while the Chenopodiaceae pollen percentage increases to an average of $50 \%$. The Compositae, Nitraria, and Ephedra pollen percentages increase to averages of $2.8 \%, 3 \%$ and $2.5 \%$. During the late Holocene, after 1.6 cal ka BP, the Chenopodiaceae pollen percentage increases to an average of $30 \%$; the average Ephedra pollen percentage increases to $5 \%$, reaching the maximum value in the Holocene. 


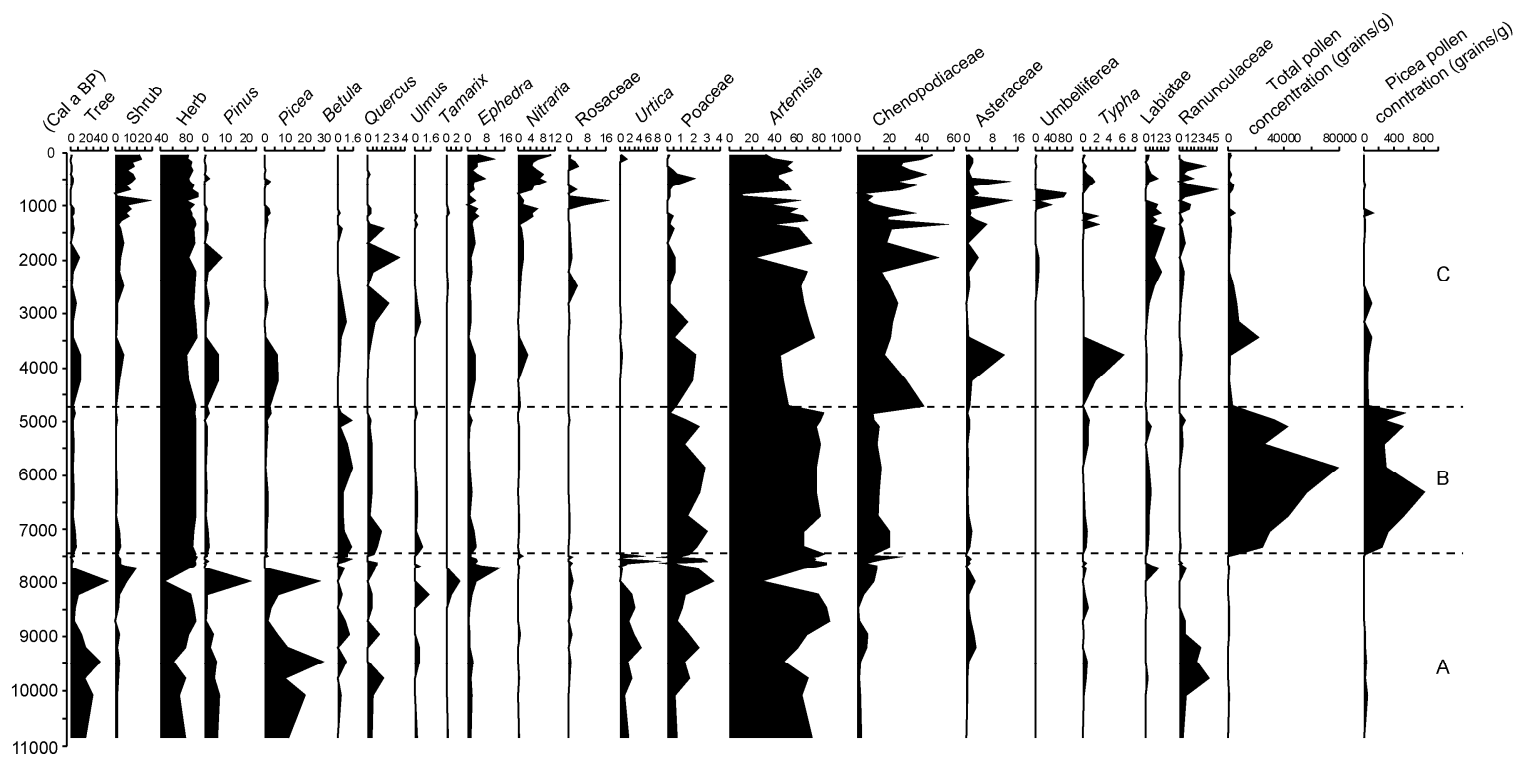

Figure 5 Pollen percentage and concentration diagram for the QTH02 section plotted against age, which can be divided into A, B and C phases. The pollen data are from $[21,22]$.

\subsection{Holocene palynological records for the QTL-03 section}

The QTL-03 section is also located in the middle of Zhuye Lake (Figure 3); the dating and pollen analysis were completed by Zhao et al. [23]. A total of 88 pollen samples were collected from the section, and 50 pollen types are identified. The section can be divided into $\mathrm{A}, \mathrm{B}, \mathrm{C}$ and $\mathrm{D}$ phases (Figure 6). During phase A (7.2-5.2 cal ka BP), the Artemisia, Chenopodiaceae, Gramineae pollen are dominant. The Artemisia pollen percentages are between $60 \%$ and $70 \%$; the average Chenopodiaceae and Gramineae pollen percentages are $25 \%$ and $15 \%$. The average total pollen concentration is 30000-40000 grains/g. During phase B (5.2-4.3 cal ka BP), the Chenopodiaceae pollen content is high, making an average contribution of $50 \%$; the Artemisia pollen percentages are $20 \%-40 \%$. The Compositae pollen is as high as $80 \%$. The percentages of Ranunculaceae and Ephedra pollen reach the highest level during the Holocene. The average total pollen concentration is 1000 grains/g. During phase C (4.3-3.5 cal ka BP), the pollen percentage of Artemisia increases, averaging $87 \%$. The pollen percentages of Chenopodiaceae and Gramineae are $15 \%$ and $10 \%$. The total pollen concentration is $1000-5000$ grains/g. During phase D (3.5-0 cal ka BP), the pollen percentage of $\mathrm{Ar}$ temisia is lower, mostly in the range of $10 \%-20 \%$. The percentage of Nitraria pollen is higher, averaging $32 \%$. According to the pollen percentages of Chenopodiaceae and Compositae, this phase can be divided into two parts. During 3.5-3.0 cal ka BP, the pollen percentage of Compositae is high, averaging $95 \%$, and the total pollen concentration is 500-3000 grains/g. During 3000-0 cal a BP, the pollen percentage of Chenopodiaceae is high, averaging $70 \%$, and the total pollen concentration is less than 600 grains/g.

\subsection{Holocene palynological records for the Sanjiao- cheng section}

The Sanjiaocheng section is located in the western part of Zhuye Lake (Figure 3). The dating and pollen analysis were completed by Chen et al. [24]. A total of 232 pollen samples were collected from the Sanjiaocheng section, and more than 50 pollen types are identified. The section can be divided into A, B and C phases (Figure 7). During phase A (11.6-7.1 cal ka BP), the percentages of coniferous pollen are high, with Sabina, Picea and Pinus accounting for 50\%$90 \%$ of the total. The pollen percentages of broad-leaved trees are $1 \%-11 \%$, and fern spores account for an average of $4 \%$. Shrub and herb pollen percentages are $1 \%-12 \%$ and $2 \%-18 \%$. The total pollen concentration is high, peaking at 2000-3000 grains/g and averaging 400-1500 grains/g. During phase B (7.1-3.8 cal ka BP), the pollen assemblages are dominated by herbs and desert plants, and there is only a small fraction of coniferous pollen. The average percentage of shrub pollen is $10 \%$, but it is as high as $70 \%$ in some layers (at 5.5 cal ka BP). The average percentage of herbs is $20 \%$. The amount of Nitraria pollen increases significantly, and is as high as $90 \%$ in some layers. The total pollen concentration reaches the lowest level during the Holocene. During phase C (3.8-0 cal ka BP), the total pollen concentration ranges from 100 to 6000 grains/g. Pollen assemblages can be divided into two types. During 2.4-1.9 and 1.1-0.5 cal ka BP, the total pollen concentration is relatively high, and the percentages of coniferous pollen are $38 \%-80 \%$. The pollen content of the aquatic plant Typha is also relatively high. In other layers, the total pollen concentration is relatively low, 


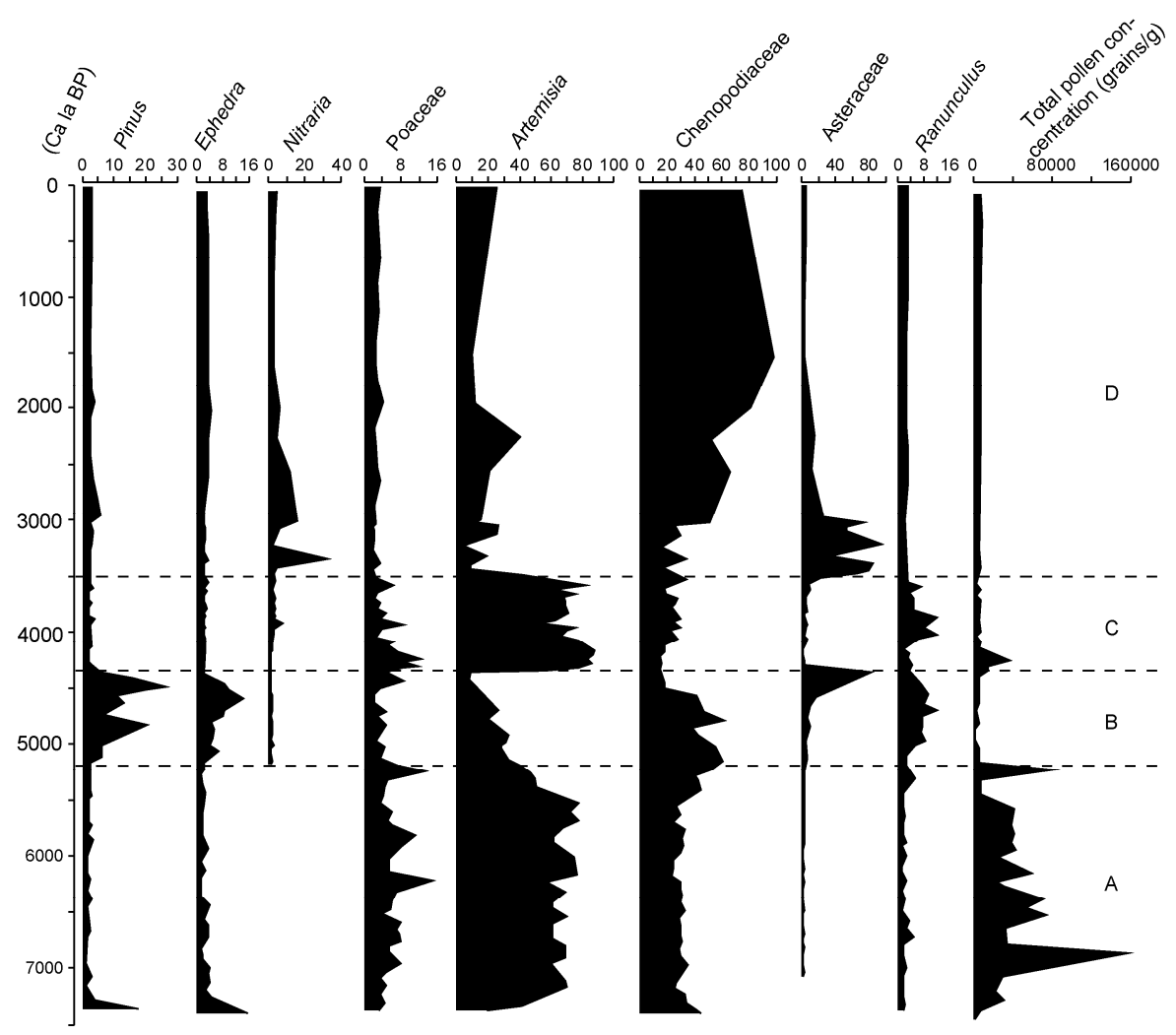

Figure 6 Pollen percentage and concentration diagram for the QTL-03 section plotted against age, which can be divided into A, B, C and D phases. The pollen data are from [23].

the herb and shrub pollen contents are relatively high, and the percentage of aquatic pollen is low. The coniferous pollen content is $11 \%-70 \%$, and is mainly contributed by $\mathrm{Sa}$ bina.

\subsection{Holocene palynological records for the Hongshuihe section}

The Hongshuihe section is composed of a Late Glacial section and Holocene section, $1 \mathrm{~km}$ apart. The dating and pollen analysis were completed by Zhang et al. [40] and Ma et al. [41]. The Late Glacial section can be divided into A, B and $C$ phases (Figure 8). During phase A (13.6-12.2 cal ka $\mathrm{BP})$, the pollen assemblages are dominated by herbaceous plants, Artemisia, Chenopodiaceae and Gramineae. The tree pollen contents are relatively high, with Picea and Pinus being dominant. During phase B (12.2-11.6 cal ka BP), the concentration of tree pollen decreases significantly, and the herbs are still dominant in the pollen assemblages, in which the average pollen percentages of Artemisia, Compositae and Chenopodiaceae are 27.8\%, 21\% and 14.6\%. During phase C (11.6-9.7 cal ka BP), the pollen contents of $\mathrm{Ar}$ temisia, Chenopodiaceae and Gramineae are still high; however, the contents of Picea and Pinus pollen increase.

The Holocene section can be divided into nine phases (Figure 8). During phase D (8450-7950 cal a BP), the total pollen concentration is low, with there being a high per- centage content of herbaceous pollen. On average, there is $62.52 \%$ Artemisia pollen and $6.92 \%$ Chenopodiaceae pollen. During phase E (7950-7500 cal a BP), the total pollen concentration and Typha pollen percentage increase; however, the pollen content of herbs decreases. During phase F (7500-6490 cal a BP), the total pollen concentration reaches a maximum for this section. The pollen types are abundant in this phase. The average percentages of Pinus, Ephedra, Picea, Gramineae and Chenopodiaceae are $8.36 \%$, 5.73\%, $19.18 \%, 15.27 \%$ and $15.27 \%$ respectively. The average percentage of coniferous pollen increases from $18.00 \%$ (phase E) to $31.09 \%$. During phase G (6490-6290 cal a $\mathrm{BP})$, the total pollen concentration is relatively high, and the coniferous pollen represented by Picea increases from $19.18 \%$ (phase F) to $49.50 \%$. During phase H (6290-5670 cal a BP), the total pollen concentration is low, and the pollen percentages of Artemisia and Chenopodiaceae are high, averaging $53.16 \%$ and $10.77 \%$. During phase I (5670-5010 cal a BP), the total pollen concentration is low, and the average pollen percentages of Pinus and Picea are $35.17 \%$ and $17.33 \%$. During phase J (5010-4470 cal a BP), the total pollen concentration is low, and the average pollen percentages of Artemisia and Chenopodiaceae are $25.55 \%$ and 20.14\%. The average pollen percentages of Pines and Picea are $29.14 \%$ and $14.86 \%$. During phase K (4470-3510 cal a $\mathrm{BP})$, the total pollen concentration is low, and the content of coniferous pollen is high, averaging $68.07 \%$. During phase 


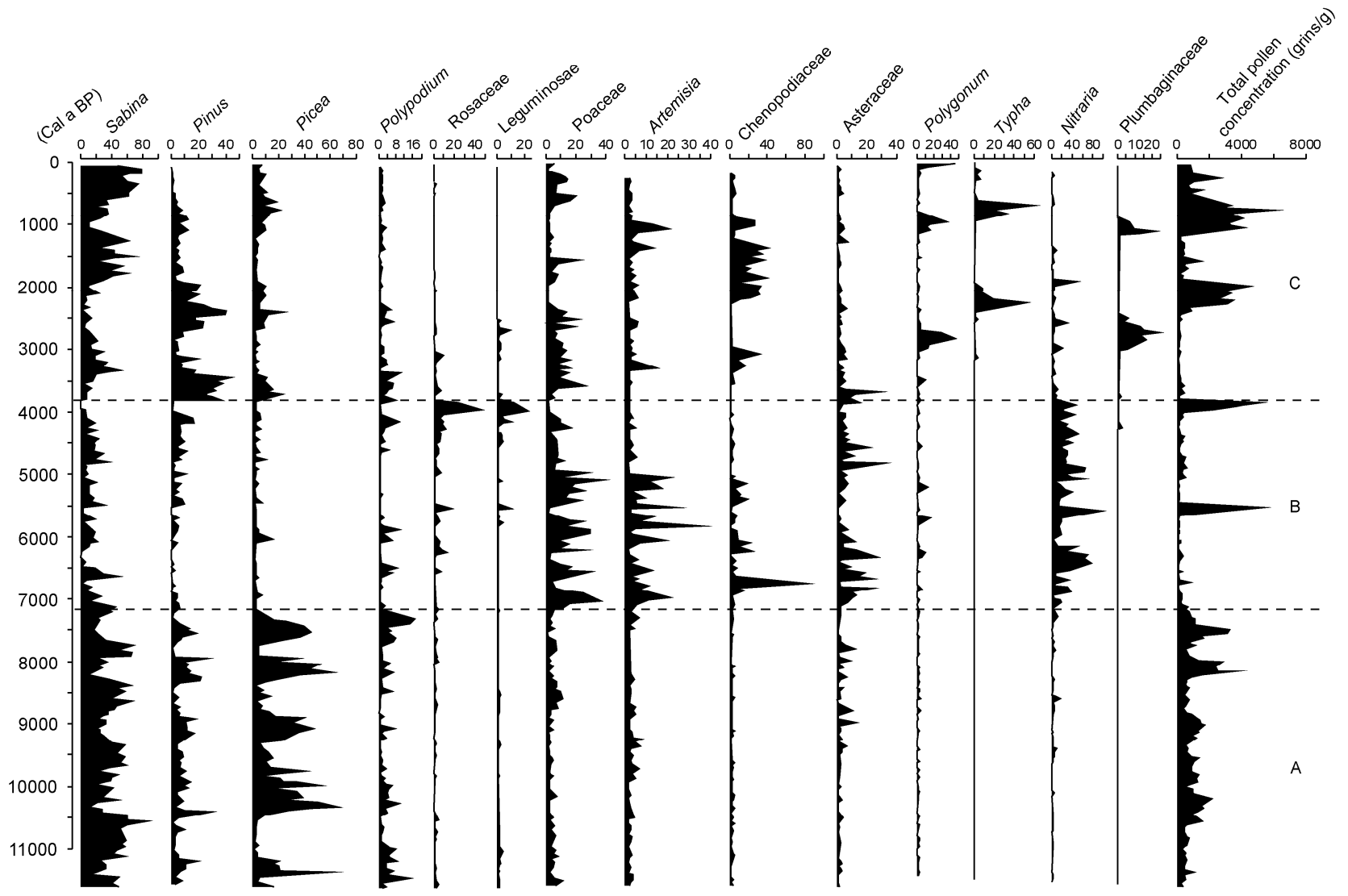

Figure 7 Pollen percentage and concentration diagram for the Sanjiaocheng section plotted against age, which can be divided into A, B, C and D phases. The pollen data are from [24].

L (3510-3230 cal a BP), the percentages of Typha and Potamogeton pollen are high, indicating an aquatic environment.

\section{Pattern of Holocene climate change in the northwest margin of the Asian monsoon revealed by basin-wide palynological records}

In this paper, the study area is an arid and semiarid region, and the fluvial-lacustrine sedimentary facies change as the water cycle changes in the basin. The lake sediments are often interrupted by aeolian sediments, and this has a large effect on the pollen assemblages. Li et al. [22] encountered this problem while studying pollen assemblages in the QTH02 section. This article examines the relationship among Holocene pollen assemblages in different sections; to account for the effects of interruption, the Picea pollen content is used as the criterion. According to modern pollen transportation studies of the Shiyang River basin [44], Picea pollen is mainly transported by rivers in the middle and lower reaches of the basin, and little Picea pollen is transported by wind to the middle and lower regions. Accordingly, Picea pollen is abundant in the fluvial-lacustrine sediments; however, there is little in the aeolian sediments.
If the lake sediments are interrupted by aeolian sediments, the Picea pollen content must change on a large scale; therefore, from the variations in Picea pollen content, changes in sedimentary facies can be detected. According to the pollen assemblages in the three sections of Zhuye Lake, the QTL-03 section is similar to the QTH02 section. In the QTL-03 section, the mid-Holocene (7.2-5.2 cal ka BP) is characterized by a high total pollen concentration (30000-40000 grains/g) and is dominated by Artemisia, Chenopodiaceae and Gramineae pollen. Zhao et al. [23] recognized the mid-Holocene as the Holocene Climatic Optimum. In the QTH02 section, the average total pollen concentration is 38634 grains/g during the mid-Holocene (7.4-4.7 cal ka BP), reaching the highest level of the Holocene, and the pollen assemblages are dominated by $A r$ temisia and Chenopodiaceae. From the mid-Holocene ( 5.0 cal ka BP) onward, there is a decrease in the total pollen concentration in both sections, along with the increases in the pollen concentrations of Chenopodiaceae, Nitraria, Ephedra and other xerophytic plants, showing the tendency of a dry climate. In the Sanjiaocheng section during the early Holocene (11.6-7.1 cal ka BP), the total pollen concentration is high, as represented by Picea, Pinus and Sabina pollen concentrations. During the mid-Holocene (7.1-3.8 cal ka BP), the total pollen concentration is low, 


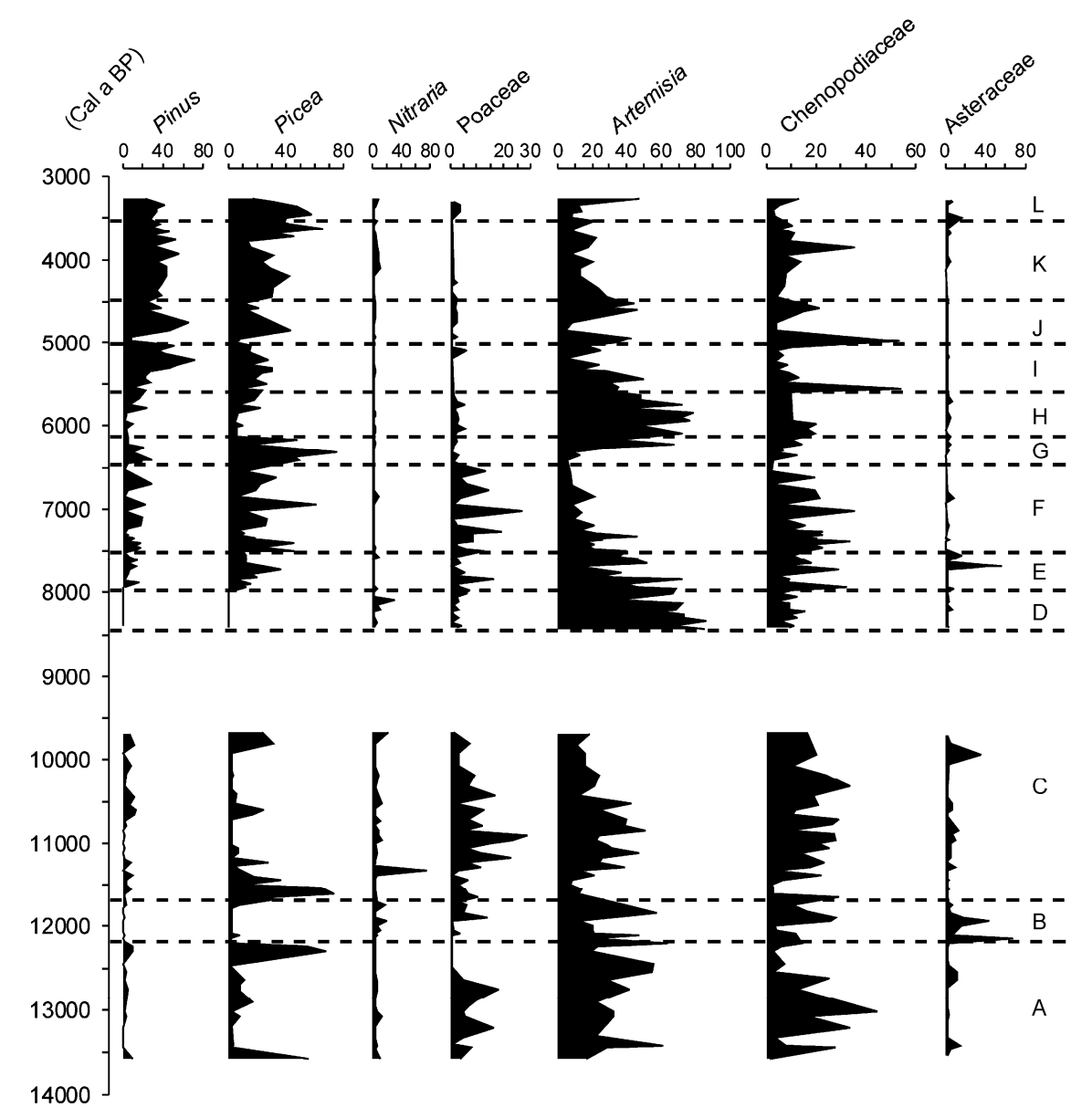

Figure 8 Pollen percentage diagram for the Hongshuihe section plotted against age, which can be divided into A, B, C, D, E, F, G, H, I, J, K and L phases. The pollen data are from [40,41]. There are two Hongshuihe sections: one is for the Holocene and the other is for the Late Glacial. The pollen percentage diagram is drawn by combining pollen data obtained for the two sections. In the two sections, there is no sediment between 9.5 and 8.5 cal ka BP; therefore, there are no values at that time in the diagram.

and shrubs and herbs are abundant. During the late Holocene, the pollen assemblages change greatly, showing the instability of climate change. Chen et al. [24] recognized that the early Holocene was characterized by a humid climate and the spread of trees in the upper region. In the QTH02 section during the early Holocene (11.0-7.4 cal ka $\mathrm{BP})$, the percentages of arboreal pollen represented by Picea and Pinus reach the highest level during the Holocene. According to the arboreal pollen percentages, the QTH02 section is similar to the Sanjiaocheng section. Zhu et al. [44] studied the pollen assemblages in the air, surface soil, river water and alluvial sediments of the Shiyang River basin; the results show that the river played a more important role than wind in pollen transportation. Pollen in the alluvial sediments was mostly transported by the river, and Picea pollen in the terminal lake was also transported by the river. Lü et al. [45] studied Picea and Abies pollen distributions on the Tibetan Plateau and in adjacent areas; the results show both pollen types were mainly distributed at an altitude of 2500-4000 m, where the average annual tem- perature was $-1^{\circ} \mathrm{C}$ to $10^{\circ} \mathrm{C}$ and the average annual rainfall was $450-850 \mathrm{~mm}$. The climate conditions are clearly different from the characteristics of Zhuye Lake; this also suggests the river transportation of Picea pollen. Picea lives in cold-wet environments [46], and numerical analysis of the climate response of Picea pollen showed the abundance of the pollen was controlled by the humidity [47]; thus, Picea pollen in Zhuye Lake can be controlled by the humidity conditions in the upper region of the basin. During a period of high precipitation, Picea trees became more dominant, and the greater flow of river water would transport more Picea pollen to the terminal lake. In the QTH02 and Sanjiaocheng sections during the early Holocene, the high percentages of Picea pollen indicate a relatively humid climate in the upper region. However, what caused the large differences in pollen assemblages between the three sections during the mid-Holocene? Figure 3 shows that the QTH02 and QTL-03 sections are located in the central part of Zhuye Lake, while the Sanjiaocheng section is located in the western part, far from the other sections. Xu et al. [48] 


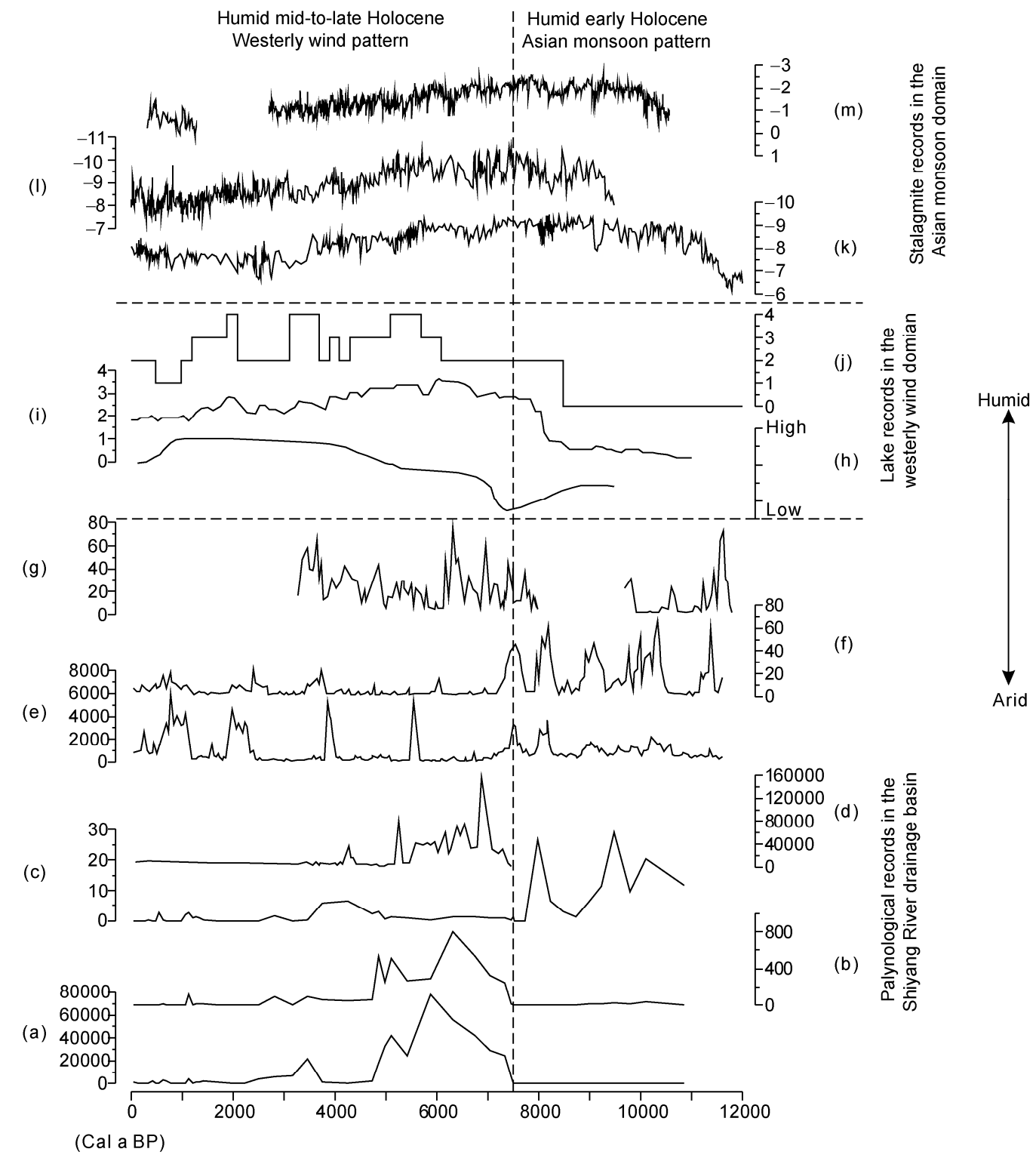

Figure 9 Compilation of typical palynological records for the Shiyang River drainage basin, the Holocene stalagmite records for the Asian monsoon domain, and the Holocene lake records for arid Central Asia. The typical pollen records for the Shiyang River drainage basin show (a) total pollen concentration (grains/g), (b) Picea pollen concentration (grains/g) and (c) Picea pollen percentages (\%) in the QTH02 section [21,22], (d) total pollen concentration (grains/g) in the QTL-03 section [23], (e) total pollen concentration (grains/g) and (f) Picea pollen percentages (\%) in the Sanjiaocheng section [24], and (g) Picea pollen percentages (\%) in the Hongshuihe Section [40,41]. The lake records for arid Central Asia show (h) lake level changes for Wulungu Lake [51], (i) the average humidity index for 11 lakes (Lake Van, Aral Sea, Issyk-Kul, Wulun Lake, Bosten Lake, Bayan Nuur, Telmen Lake, Hovsgol Nuur, Juyan Lake, Gun Nuur, Hulun Nuur) in arid Central Asia[16] and (j) humidity index of Bosten Lake[16]. The Holocene stalagmite records for the Asian monsoon domain show (k) Dongge Cave $\delta^{18} \mathrm{O}(\%)$ [10], (l) Heshang Cave $\delta^{18} \mathrm{O}(\% \circ)$ [11] and (m) Qunf Cave $\delta^{18} \mathrm{O}(\%)$ [12].

studied pollen assemblages taken from the surface sediments of Daihai Lake; the results show very different assemblages in different locations. The differences are mainly due to vegetation near lakeshores. Huang et al. [49] studied the pollen assemblages from lake surface sediments of Bosten Lake; the results show the total pollen concentration was much higher in the central part. The Picea pollen percentages were higher near the estuary because Picea pollen is mainly transported by river. These studies show that the pollen assemblages differ at different locations of the lake basin; therefore, the pollen assemblages in the Sanjiaocheng section are quite different from those in the other two sections. In addition, studies of the lake geomorphology show that the lake level never exceeded $1308 \mathrm{~m}$ during the Holocene epoch; the lake level during the mid-Holocene was 1306-1308 $\mathrm{m}$ above sea level $[38,39]$. The QTH02 section is at $1309 \mathrm{~m}$ and the QTL-03 section is at $1302 \mathrm{~m}$; the mid-Holocene sediments in these two sections are mainly 3 $\mathrm{m}$ from the top; therefore, the two sections are at 1306 and $1299 \mathrm{~m}$ above sea level during the mid-Holocene. The 
Sanjiaocheng section is at an elevation of $1320 \mathrm{~m}$, and the mid-Holocene sediments are 3-4 $\mathrm{m}$ from the top; thus, the section is 1316-1317 $\mathrm{m}$ above sea level during the mid-Holocene, which is far higher than the mid-Holocene lake level. Therefore, the pollen assemblages may be affected by the local topography, hydrology and vegetation conditions. In the QTH02 and QTL-03 sections, during the mid-Holocene ( $\sim .0$ to $\sim 5.0$ cal ka BP), the high total pollen concentration and Picea pollen concentration indicate a high level of vegetation cover in the basin; the low tree pollen percentages may be due to the flourishing of herbs.

The Hongshuihe section is located in the middle reaches of the Shiyang River basin. During 12.2-11.6 cal ka BP, the Picea pollen content significantly declined, indicating a dry climate in the upper mountains, which corresponds to a weaker Asian monsoon during the Younger Dryas event [50]. During 11.6-9.7 cal ka BP, the quantities of Picea and Pines pollen increase significantly, indicating a relatively humid climate in the upper region, which may be correlated to the enhanced Asian monsoon. During 8.5-3.0 cal ka BP, the Hongshuihe section can be divided into nine phases according to the pollen assemblages. During 7.5-3.5 cal ka BP, most of the layers are characterized by a high content of arboreal pollen represented by Picea, indicating high precipitation and humid conditions in the upper mountains. However, during the mid-Holocene, there are a variety of significant fluctuations in the pollen assemblages, which might represent millennium-scale climate fluctuations. From 3.5 cal a BP onward, Typha and Potamogeton pollen contents are relatively high, indicating an environment of still water.

The Shiyang River basin is located in the northwest margin of the Asian monsoon. Comparing the basin-wide palynological records with Holocene records for the Asian monsoon domain and westerly wind region, the Holocene climate mechanism can be explored. In the Asian monsoon domain, three absolutely dated Holocene stalagmite records for different locations are selected (Dongge Cave [10], Heshang Cave [11] and Qunf Cave [12]). In the westerly wind domain, two typical Holocene lake records are chosen (Bosten Lake [16] and Wulungu Lake [51]), and the average humidity index of 11 lakes in arid Central Asia is used [16]. In Figure 9, the comparison among the Picea pollen percentages at the QTH02, Sanjiaocheng and Hongshuihe sections shows high Picea pollen percentages during the early Holocene, which indicates a relatively humid climate in the upper mountains of the Shiyang River basin. The result is consistent with the strong Asian monsoon during the early Holocene. During the mid-Holocene, the QTH02 and QTL-03 sections are characterized by a high total pollen concentration and a high Picea pollen concentration, which indicate a high level of vegetation cover and a humid climate in the basin. In the middle reaches of the basin, the relatively high Picea pollen percentages also suggest a hu- mid climate during 7.5-3.5 cal ka BP. The mid-Holocene humid climate indicated by the basin-wide palynological records is consistent with the humid mid-Holocene conditions in arid Central Asia, where the Holocene westerly wind pattern prevails. From $\sim 5.0$ cal ka BP onward, the pollen assemblages in the QTH02 and QTL-03 sections show the climate to have a dry tendency. The still-water conditions indicated by the Hongshuihe section in the middle reaches of the basin may be related to reduced water flow from the upper mountains, which can be considered a result of the weakened late-Holocene Asian monsoon. Overall, the Holocene climate changes in the basin reflect and can be controlled by the combined effects of the Asian monsoon and westerly wind. This study presents the complicated process of Holocene climate change. For further exploration of the climate change mechanism in the northwest margin of the Asian monsoon, high-resolution records and climate models are needed.

It is seen that pollen assemblages are quite different at four locations in the basin. Only using the pollen assemblages from one location to discuss past climate change is insufficient and limited. In this study, we did not use the Artemisia and Chenopodiaceae ratios as an indicator of paleoclimate because the sedimentary facies of the four sections differ significantly, meaning that environmental effects would not be obvious.

We thank Professor Xu Qinghai and Li Yuecong of Hebei Normal University for assistance in the pollen identification. We are particularly grateful to Professor Zhang Hucai for his suggestions regarding the mechanisms of the climate system and sedimentation. Special thanks are also given to the editors and reviewers for their suggestions for improving our paper. This work was supported by the National Natural Science Foundation of China (41001116 and 58079033) and the Fundamental Research Fund for the Central Universities (LZUJBKY-2010-99).

1 PAGES Scientific Steering Committee. Science Plan and Implementation Strategy. IGBP Report No. 57, IGBP. 2009

2 He Y, Wilfred H, Zhang Z, et al. Asynchronous Holocene climatic change across China. Quat Res, 2004, 61: 52-63

3 An Z S, Porter S C, Kutzbach J E, et al. Asynchronous Holocene optimum of the East Asian monsoon. Quat Sci Rev, 2000, 19: 743-762

4 An C, Feng Z, Barton L. Dry or humid? Mid-Holocene humidity changes in arid and semiarid China. Quat Sci Rev, 2006, 25: 351-361

5 Feng Z D, An C B, Tang L Y, et al. Stratigraphic evidence of megahumid mid-Holocene climate in the western part of the Chinese Loess Plateau. Glob Planet Change, 2004, 43: 145-155

6 Tao S, Chen L. A review of recent research on the East Asian summer monsoon in China. In: Chang C P, Krishnamurti T N, eds. Monsoon Meteorology. Oxford: Oxford University Press, 1987. 60-92

7 Wang B, Lin H. Rainy season of the asian-pacific summer monsoon. J Clim, 2002, 15: 386-398

8 Hong Y, Hong T, Lin Q, et al. Inverse phase oscillations between the East Asian and Indian Ocean summer monsoons during the last 12000 years and paleo-El Niño. Earth Planet Sci Lett, 2005, 231: 337-346

9 Yang Y, Yuan D, Cheng H, et al. Precise dating of abrupt shifts in the Asian Monsoon during the last deglaciation based on stalagmite data from Yamen Cave, Guizhou Province, China. Sci China Earth Sci, 2010, 53: 633-641

10 Dykoski C A, Edwards R L, Cheng H, et al. A high-resolution, abso- 
lute-dated Holocene and deglacial Asian monsoon record from Dongge Cave, China. Earth Planet Sci Lett, 2005, 233: 71-86

$11 \mathrm{Hu}$ C, Henderson G M, Huang J, et al. Quantification of Holocene Asian monsoon rainfall from spatially separated cave records. Earth Planet Sci Lett, 2008, 266: 221-232

12 Fleitmann D, Burns S J, Mudelsee M, et al. Holocene forcing of the indian monsoon recorded in a stalagmite from Southern Oman. Science, 2003, 300: 1737-1739

13 Chinese Academy of Sciences (Compilatory Commission of Physical Geography of China). Physical Geography of China: Climate (in Chinese). Beijing: Science Press, 1984

$14 \mathrm{Li} \mathrm{J}$. The patterns of environmental changes since late Pleistocene in northwestern China (in Chinese). Quat Sci, 1990, 3: 197-204

15 Herzschuh U. Palaeo-moisture evolution in monsoonal Central Asia during the last 50000 years. Quat Sci Rev, 2006, 25: 163-178

16 Chen F, Yu Z, Yang M, et al. Holocene moisture evolution in arid central Asia and its out-of-phase relationship with Asian monsoon history. Quat Sci Rev, 2008, 27: 351-364

$17 \mathrm{Li} \mathrm{X}$, Zhou W, An Z, et al. The vegetation and monsoon variations at the desert-loess transition belt at Midiwan in northern China for the last $13 \mathrm{ka}$. Holocene, 2003, 13: 779-784

18 Xiao J, Xu Q, Nakamura T, et al. Holocene vegetation variation in the Daihai Lake region of north-central China: A direct indication of the Asian monsoon climatic history. Quat Sci Rev, 2004, 23: 1669- 1679

19 Jiang W Y, Liu T S. Timing and spatial distribution of Mid-Holocene drying over northern China: Response to a south-eastward retreat of the East Asian monsoon. J Geophys Res, 2007, 112: D24111, doi: 10.1029/2007JD009050

20 Wen R, Xiao J, Chang Z, et al. Holocene precipitation and temperature variations in the East Asian monsoonal margin from pollen data from Hulun Lake in northeastern Inner Mongolia, China. Boreas, 2010, 39: 262-272

$21 \mathrm{Li} \mathrm{Y}$, Wang $\mathrm{N}$, Cheng $\mathrm{H}$, et al. Holocene environmental change in the marginal area of the Asian monsoon: A record from Zhuye Lake, NW China. Boreas, 2009, 38: 349-361

22 Li Y, Wang N, Morrill C, et al. Environmental change implied by the relationship between pollen assemblages and grain-size in N.W. Chinese lake sediments since the Late Glacial. Rev Palaeobot Palyno, 2009, 154: 54-64

23 Zhao Y, Yu Z, Chen F H, et al. Holocene vegetation and climate change from a lake sediment record in the Tengger Sandy Desert, northwest China. J Arid Environ, 2008, 72: 2054-2064

24 Chen F H, Cheng B, Zhao Y, et al. Holocene environmental change inferred from a high-resolution pollen record, Lake Zhuyeze, arid China. Holocene, 2006, 16: 675-684

25 Chen F H, Wu W, Zhu Y, et al. A mid-Holocene drought interval as evidenced by lake desiccation in the Alashan Plateau, Inner Mongolia, China. Chinese Sci Bull, 2003, 48: 1401-1410

26 Zhao S Q. A new scheme for comprehensive physical regionalization in China (in Chinese). Acta Geogr Sin, 1983, 38: 1-10

27 Wang $\mathrm{K}$, Jiang $\mathrm{H}$, Zhao $\mathrm{H}$. Atmospheric water vapor transport from westerly and monsoon over the Northwest China (in Chinese). Adv Water Sci, 2005, 16: 432-438

$28 \mathrm{Li} \mathrm{W}$, Wang K, Fu S, et al. The interrelationship between regional westerly index and the water vapor budget in Northwest China (in Chinese). J Glaciol Geocryol, 2008, 30: 38-34

29 Dong L, Guo P, Wang P, et al. Impacts of the variation of westerly jets over East Asia in July on the precipitation of East China (in Chinese). Plateau Meteorol, 2010, 29: 286-296

30 Du Y, Zhang Y, Xie Z. Impacts of longitude location changes of East Asian westerly jet core on the precipitation distribution during meiyu period in middle-lower reaches of Yangtze River valley (in Chinese). Acta Meteorol Sin, 2008, 66: 566-576

31 Kuang X, Zhang Y, Liu J. Relationship between subtropical upper tropospheric westerly jet and East Asian Winter Monsoon (in Chinese). Plateau Meteorol, 2008, 27: 701-712

32 Chen L H, Qu Y G. Water-land Resources and Reasonable Development and Utilization in the Hexi Region (in Chinese). Beijing: Science Press, 1992. 77-78

33 Huang D X. Gansu Vegetation (in Chinese). Lanzhou: Gansu Science and Technology Press, 1997. 189-213

34 Feng S W. The evolution of the drainage system of the Minchin Oasis (in Chinese). Acta Geogr Sin, 1963, 29: 241-249

35 Li B C. A study on the Zhuye Lake and its historical evolution (in Chinese). Acta Geogr Sin, 1993, 48: 55-60

36 Pachur H J, Wünnemann B, Zhang H C. Lake evolution in the Tengger Desert, Northwest China, during the last 40000 years. Quat Res, 1995, 44: 171-180

37 Zhang H C, Ma Y Z, Li J J, et al. Palaeolake evolution and abrupt climate changes during last glacial period in NW China. Geophys Res Lett, 2001, 28: 3203-3206

38 Zhang H C, Peng J L, Ma Y Z, et al. Late Quat palaeolake levels in Tengger Desert, NW China. Palaeogeogr Palaeoclimatol Palaeoecol, 2004, 211: 45-48

39 Long H, Wang N, Li Y, et al. Mid-Holocene climate variations from lake records of the east asian monsoon margin: A multi-proxy and geomorphological study (in Chinese). Quat Sci, 2007, 27: 371-381

40 Zhang H C, Ma Y Z, Wünnemann B. A Holocene climatic record from arid northwestern China. Palaeogeogr Palaeoclimatol Palaeoecol, 2000, 162: 389-401

41 Ma Y, Zhang H, Pachur H J, et al. Late Glacial and Holocene vegetation history and paleoclimate of the Tengger Desert, northwestern China. Chinese Sci Bull, 2003, 48: 1457-1463

42 Wang N, Zhang J, Cheng H, et al. The age of formation of the mirabilite and sand wedges in the Hexi Corridor and their paleoclimatic interpretation. Chinese Sci Bull, 2003, 48: 1439-1445

43 Chen F H, Zhu Y, Li J J, et al. Abrupt Holocene changes of the Asian monsoon at millennial- and centennial-scales: Evidence from lake sediment document in Minqin Basin, NW China. Chinese Sci Bull, 2001, 46: 1942-1947

44 Zhu Y, Cheng B, Chen F H, et al. Preliminary studies on pollen transport in the Shiyang River drainage, Arid China. Chinese Sci Bull, 48: 1499-1506

45 Lü H Y, Wu N Q, Yang X D, et al. Spatial pattern of Abies and Picea surface pollen distribution along the elevation gradient in the Qinghai-Tibetan Plateau and Xinjiang, China. Boreas, 2008, 37: 254-262

46 The Editorial Board of Chinese Vegetation. Chinese Vegetation (in Chinese). Beijing: Science Press, 1980. 195-197

47 Sun X, Wang F, Song C, et al. Pollen-climate response surfaces of selected taxa from Northern China. Sci China Ser D-Earth Sci, 1996, 39: 486-493

48 Xu Q, Li Y, Yang X, et al. Source and distribution of pollen in the surface sediment of Daihai Lake, Inner Mongolia. Quat Int, 2005, 136: $33-45$

49 Huang X, Zhou G, Ma Y, et al. Pollen distribution in large freshwater lake of arid region: A case study on the surface sediments from Bosten Lake, Xinjiang, China. Front Earth Sci Chin, 2010, 4: 174-180

50 Pang Y, Zhang H, Chang F, et al. Instability record of the Late Glacial in the southern Tengger Desert (in Chinese). Quat Sci, 2010, 30: 69-79

51 Liu X, Herzschuh U, Shen J, et al. Holocene environmental and climatic changes inferred from Wulungu Lake in northern Xinjiang, China. Quat Res, 2008, 70: 412-425

Open Access This article is distributed under the terms of the Creative Commons Attribution License which permits any use, distribution, and reproduction in any medium, provided the original author(s) and source are credited. 